\title{
Perbedaan Dukungan Nenek dalam Keluarga Extended Family pada Pemberian ASI Eksklusif dan Tidak Eksklusif di Wilayah Kerja Puskesmas Arjasa Kabupaten Jember (The Differences of Grandmother Support in Extended Family on Exclusive and Non-Exclusive Breastfeeding in Working Area of Arjasa Public Health Center, Jember)
}

\author{
Dina Amalia, Ratna Sari Hardiani, Lantin Sulistyorini \\ Fakultas Keperawatan Universitas Jember \\ Jl. Kalimantan No. Kampus Tegal Boto Jember 37 Telp./Fax. (0331) 323450 \\ e-mail: ratna.sari@unej.ac.id
}

\begin{abstract}
The rate of exclusive breastfeeding in Jember still low, it's about $69.27 \%$ from the target is $80 \%$. One factors of that is the lackness of family support, especially grandmother. Grandmother mantain to give early complementary foods to baby because of cultural reasons. The aim of this study was to analyze the differences of grandmother support in extended family on exclusive and non-exclusive breastfeeding in working area of Arjasa public health center. This research used an observational analytic design with Retrospective approach. The subjects was 66 mothers with babies aged 7-12 months which divided in two groups, 22 of mothers who breastfeed exclusively dan 44 mothers who breastfeed not exclusively that collected by multistage random sampling. Instrument used questionnaire. The analysis based on statistical Mann-Whitney showed $p$ value $=0.001$ ( $p$ value < $\alpha=0.05)$. It means there are the differences of grandmother support in extended family on exclusive and non-exclusive breastfeeding. Grandmothers can affect the mothers to decided breastfeed exclusively. Informational support is the most important support to mothers. Health workers need to improve mothers's knowledge and involve grandmothers as effort giving exclusive breastfeeding, so the rate of exclusive breastfeeding can be increased.
\end{abstract}

Keywords: grandmother support, exclusive, non-exclusive, breastfeeding

\begin{abstract}
Abstrak
Cakupan ASI eksklusif di Kabupaten Jember masih rendah, yaitu $69.27 \%$ dari target yang ditetapkan yaitu $80 \%$. Salah satu faktor yang mempengaruhi hal tersebut adalah rendahnya dukungan dari keluarga, terutama nenek. Nenek mempertahankan untuk memberikan makanan tambahan secara dini kepada bayi dengan alasan budaya. Tujuan dari penelitian ini adalah untuk menganalisis perbedaan dukungan nenek dalam extended family pada pemberian ASI eksklusif dan tidak eksklusif di Wilayah Kerja Puskesmas Arjasa. Penelitian ini menggunakan desain observasional analitik dengan pendekatan restrospektif. Subyek penelitian adalah 66 ibu dengan bayi usia 7-12 bulan yang dibagi menjadi dua kelompok, 22 ibu yang memberikan ASI eksklusif dan 44 ibu yang memberikan ASI tidak eksklusif yang diambil secara multistage random sampling. Instrumen menggunakan kuesioner. Analisis berdasarkan uji statistik Mann-Whitney menunjukkan $p$ value $=0,001$ ( $p$ value $<\alpha=0.05$ ). Hal ini berarti terdapat perbedaan dukungan nenek dalam extended family pada pemberian ASI eksklusif dan tidak eksklusif. Nenek dapat mempengaruhi keputusan ibu untuk memberikan ASI eksklusif. Dukungan informasional adalah dukungan yang paling penting untuk ibu. Petugas kesehatan perlu meningkatkan pengetahuan ibu dan melibatkan nenek dalam upaya pemberian ASI eksklusif sehingga angka cakupan ASI eksklusif dapat ditingkatkan.
\end{abstract}

Kata kunci: dukungan nenek, eksklusif, tidak eksklusif, pemberian ASI 


\section{Pendahuluan}

Kesehatan seorang individu dapat ditentukan dari keadaan gizinya. Asupan gizi yang optimal sangat penting untuk pertumbuhan normal serta perkembangan fisik dan kecerdasan seseorang [1]. Salah satu jenis makanan bergizi pada awal-awal kehidupan adalah Air Susu Ibu (ASI). ASI adalah makanan bayi yang paling penting karena mengandung berbagai macam zat gizi yang dibutuhkan oleh bayi [2]. World Health Organization (WHO) dan The United Nations Children's Fund (UNICEF) merekomendasikan pemberian ASI kepada bayi disarankan setidaknya sampai usia 6 bulan tanpa makanan tambahan lain dan dilanjutkan sampai anak berusia 2 tahun atau lebih [3]. Selain mengandung zat gizi, pemberian ASI eksklusif juga memiliki manfaat positif baik pada ibu dan keluarga. Namun kurangnya pemahaman masyarakat tentang manfaat ASI menyebabkan masih rendahnya angka cakupan ASI eksklusif [4].

Menurut Ditjen Bina Gizi dan KIA dalam Profil Kesehatan Indonesia cakupan ASI eksklusif pada bayi di Indonesia secara nasional sebesar $54,3 \%$. Provinsi Jawa Timur menempati peringkat 8 dari 33 provinsi yaitu sebesar $47,9 \%$. Rendahnya cakupan ASI eksklusif ini salah satunya disebabkan karena rendahnya dukungan dari keluarga, terutama nenek. Nenek cenderung ingin mempertahankan budayanya untuk mengenalkan makanan tambahan secara dini kepada bayi [5].

Pemberian makanan sejak awal dapat menjadi faktor penyebab rendahnya pemberian ASI eksklusif [6]. Nenek dapat berperan sebagai peserta aktif dalam pengambilan keputusan keluarga termasuk pengambilan keputusan dalam pemberian ASI. Pengaruh dalam pengambilan keputusan ini terjadi karena nenek dianggap sebagai orang yang berpengalaman dan pemegang wewenang dalam keluarga [7].

Studi pendahuluan dilakukan oleh peneliti di Dinas Kesehatan Kabupaten Jember, diketahui bahwa pada tahun 2014 angka cakupan ASI eksklusif di Kabupaten Jember sebesar $69,27 \%$ dan terendah yaitu puskesmas Arjasa sebesar $35,74 \%$. Berdasarkan hasil wawancara pada 10 ibu. 5 ibu yang menyusui ASI eksklusif mengetahui informasi tentang ASI eksklusif dan nenek tidak pernah menyarankan untuk diberikan MP-ASI dini. Pada 5 ibu yang tidak menyusui ASI eksklusif mengatakan 3 ibu sebenarnya mengetahui tentang ASI eksklusif namun alasan kasihan jika hanya diberi ASI saja bayi masih kurang dan rewel. Nenek bayi yaitu ibu kandung/mertua dari ibu biasanya menyarankan untuk memberikan makanan tambahan berupa pisang, nasi dan madu pada bayinya saat usia 2 bulan. Mereka meyakini bahwa makanan tersebut membuat bayi kenyang, tidak rewel, bisa tidur nyenyak dan cepat gemuk.

Hal ini menunjukkan bahwa masih kurangnya dukungan dari nenek pada ibu untuk memberikan ASI secara eksklusif. Berdasarkan pada uraian tersebut, peneliti tertarik untuk melakukan penelitian tentang Perbedaan Dukungan Nenek dalam Extended Family pada Pemberian ASI Eksklusif dan Tidak Eksklusif di Wilayah Kerja Puskesmas Arjasa Kabupaten Jember.

\section{Metode Penelitian}

Metode penelitian ini adalah observasional analitik dengan pendekatan retrospektif. Populasi yaitu ibu yang memiliki bayi usia $7-12$ bulan dan tinggal bersama nenek (extended family). Jumlah sampel sebanyak 66 ibu yang dibagi menjadi dua kelompok yaitu 22 ibu yang memberikan ASI eksklusif dan 44 ibu yang memberikan ASI tidak eksklusif yang diambil secara multistage random sampling. Data dianalisis dengan menggunakan uji mann-whitney dengan derajat kepercayaan $95 \% \quad(\alpha=0,05)$. Etika penelitian pada penelitian ini adalah informed consent, kerahasiaan, keanoniman, kesepakatan dan keadilan.

\section{Hasil Penelitian}

\section{Karakteristik Responden}

Tabel1. Distribusi umur responden di Wilayah Kerja Puskesmas Arjasa Tahun 2016

\begin{tabular}{llll}
\hline Kelompok (Tahun) & Mean & SD & Min-Max \\
\hline $\begin{array}{l}\text { lbu yang } \\
\text { memberikan ASI } \\
\text { eksklusif }\end{array}$ & 25,14 & 4,902 & $17-34$ \\
$\begin{array}{l}\text { lbu yang } \\
\text { memberikan ASI } \\
\text { tidak eksklusif }\end{array}$ & 25,07 & 6,090 & $18-39$ \\
\hline
\end{tabular}

Tabel 2. Distribusi umur bayi di Wilayah Kerja Puskesmas Arjasa Tahun 2016

\begin{tabular}{lccc}
\hline Kelompok (Bulan) & Mean & SD & Min-Max \\
\hline $\begin{array}{l}\text { lbu yang } \\
\text { memberikan ASI }\end{array}$ & 10,55 & 1,503 & $8-12$ \\
$\begin{array}{l}\text { eksklusif } \\
\text { lbu yang }\end{array}$ & & & \\
$\begin{array}{l}\text { memberikan ASI } \\
\text { tidak eksklusif }\end{array}$ & 9,75 & 1,542 & $8-12$ \\
\hline
\end{tabular}


Amalia, et al, Perbedaan Dukungan Nenek dalam Keluarga Extended Family pada Pemberian ASI....

Tabel 3. Distribusi frekuensi responden menurut agama, suku, pendidikan, pekerjaan, pendapatan, jumlah anak, dukungan petugas kesehatan, dan promosi susu formula di Wilayah Kerja Puskesmas Arjasa Tahun 2016

\begin{tabular}{|c|c|c|c|c|c|c|c|}
\hline \multirow{3}{*}{ No } & \multirow{3}{*}{$\begin{array}{c}\text { Karakterist } \\
\text { ik } \\
\text { Responde } \\
\text { n }\end{array}$} & \multicolumn{6}{|c|}{ Distribusi Kriteria Responden } \\
\hline & & \multicolumn{2}{|c|}{$\begin{array}{c}\text { ASI } \\
\text { Eksklusif }\end{array}$} & \multicolumn{2}{|c|}{$\begin{array}{c}\text { ASI } \\
\text { Tidak } \\
\text { Eksklusi } \\
\mathbf{f}\end{array}$} & \multicolumn{2}{|c|}{ Total } \\
\hline & & $\mathbf{F}$ & $\%$ & $\mathbf{F}$ & $\%$ & $\mathbf{F}$ & $\%$ \\
\hline \multirow[t]{2}{*}{1.} & $\begin{array}{l}\text { Agama } \\
\text { Islam }\end{array}$ & 22 & 100 & 44 & 100 & 66 & 100 \\
\hline & Total & 22 & 100 & 44 & 100 & 66 & 100 \\
\hline \multirow[t]{4}{*}{2.} & Suku & & & & & & \\
\hline & Jawa & 8 & 36,4 & 15 & 34,1 & 23 & 34,8 \\
\hline & Madura & 14 & 63,6 & 29 & 65,9 & 43 & 65,2 \\
\hline & Total & 22 & 100 & 44 & 100 & 66 & 100 \\
\hline \multirow[t]{7}{*}{3.} & $\begin{array}{l}\text { Tingkat } \\
\text { Pendidikan }\end{array}$ & & & & & & \\
\hline & $\begin{array}{l}\text { Tidak } \\
\text { Sekolah }\end{array}$ & 3 & 13,6 & 0 & 0 & 3 & 4,5 \\
\hline & SD & 4 & 18,2 & 19 & 43,2 & 23 & 34,8 \\
\hline & SMP & 7 & 31,8 & 13 & 29,5 & 20 & 30,3 \\
\hline & SMA & 6 & 27,3 & 11 & 25,0 & 17 & 25,8 \\
\hline & $\begin{array}{l}\text { Perguruan } \\
\text { Tinggi }\end{array}$ & 2 & 9,1 & 1 & 2,3 & 3 & 4,6 \\
\hline & Total & 22 & 100 & 44 & 100 & 66 & 100 \\
\hline \multirow[t]{5}{*}{4.} & Pekerjaan & & & & & & \\
\hline & IRT & 19 & 86,4 & 38 & 86,4 & 57 & 86,4 \\
\hline & Pedagang & 2 & 9,1 & 0 & 0 & 2 & 3 \\
\hline & Lain-lain & 1 & 4,5 & 6 & 13,6 & 7 & 10,6 \\
\hline & Total & 22 & 100 & 44 & 100 & 66 & 100 \\
\hline \multirow[t]{3}{*}{5.} & $\begin{array}{l}\text { Pendapata } \\
\text { n }\end{array}$ & 16 & 72,7 & 40 & 90,9 & 56 & 84,9 \\
\hline & $\begin{array}{l}<1.629 .000 \\
\geq 1.629 .000 \\
\end{array}$ & 6 & 27,3 & 4 & 9,1 & 10 & 15,1 \\
\hline & Total & 22 & 100 & 44 & 100 & 66 & 100 \\
\hline \multirow[t]{4}{*}{6.} & $\begin{array}{l}\text { Jumlah } \\
\text { anak }\end{array}$ & 14 & 63,6 & 29 & 65,9 & 43 & 65,2 \\
\hline & 1 & 8 & 36,4 & 15 & 34,1 & 23 & 34,8 \\
\hline & $\geq 2$ & & & & & & \\
\hline & Total & 22 & 100 & 44 & 100 & 66 & 100 \\
\hline \multirow[t]{4}{*}{7.} & $\begin{array}{l}\text { Penyuluha } \\
\text { n tentang } \\
\text { ASI } \\
\text { eksklusif }\end{array}$ & & & & & & \\
\hline & $\begin{array}{l}\text { Mendapatk } \\
\text { an } \\
\text { penyuluhan }\end{array}$ & 19 & 86,4 & 36 & 81,8 & 55 & 83,3 \\
\hline & $\begin{array}{l}\text { Tidak } \\
\text { mendapatk } \\
\text { an } \\
\text { penyuluhan }\end{array}$ & 3 & 13,6 & 8 & 18,2 & 11 & 16,7 \\
\hline & Total & 22 & 100 & 44 & 100 & 66 & 100 \\
\hline \multirow[t]{3}{*}{8.} & $\begin{array}{l}\text { Promosi } \\
\text { susu } \\
\text { formula }\end{array}$ & & & & & & \\
\hline & Terpapar & 16 & 72,7 & 35 & 79,5 & 51 & 77,3 \\
\hline & Tidak & 6 & 27,3 & 9 & 20,5 & 15 & 22,7 \\
\hline
\end{tabular}

\begin{tabular}{lllllll}
\hline terpapar & & & & & & \\
\hline Total & 22 & 100 & 4 & 100 & 66 & 100 \\
& & & 4 & & & \\
\hline
\end{tabular}

Karakteristik nenek

Tabel 4. Distribusi rerata umur nenek di Wilayah Kerja Puskesmas Arjasa

\begin{tabular}{lccc}
\hline $\begin{array}{c}\text { Umur nenek } \\
\text { (Tahun) }\end{array}$ & Mean & SD & Min-Max \\
\hline $\begin{array}{l}\text { Pemberian ASI } \\
\text { Eksklusif }\end{array}$ & 50,86 & 8,871 & $35-65$ \\
$\begin{array}{l}\text { Pemberian ASI } \\
\text { Tidak Eksklusif }\end{array}$ & 49,16 & $\begin{array}{c}10,80 \\
7\end{array}$ & $30-85$ \\
\hline
\end{tabular}

Tabel 5.Distribusi frekuensi status nenek dengan responden di Wilayah Kerja Puskesmas Arjasa

\begin{tabular}{|c|c|c|c|c|c|c|}
\hline \multirow{3}{*}{$\begin{array}{l}\text { Status } \\
\text { nenek }\end{array}$} & \multicolumn{6}{|c|}{ Distribusi Kriteria Responden } \\
\hline & \multicolumn{2}{|c|}{$\begin{array}{c}\text { ASI } \\
\text { Eksklusif }\end{array}$} & \multicolumn{2}{|c|}{$\begin{array}{l}\text { ASI Tidak } \\
\text { Eksklusif }\end{array}$} & \multicolumn{2}{|c|}{ Total } \\
\hline & $\mathbf{F}$ & $\%$ & $\mathbf{F}$ & $\%$ & $\mathbf{F}$ & $\%$ \\
\hline $\mathrm{Ibu}$ & 17 & 77,3 & 37 & 84,1 & 54 & 81,82 \\
\hline Kandung & & & & & & \\
\hline Ibu Mertua & 5 & 22,7 & 7 & 15,9 & 12 & 18,18 \\
\hline Total & 22 & 100 & 44 & 100 & 66 & 100 \\
\hline
\end{tabular}

Hasil penelitian menunjukkan bahwa pada kelompok ibu yang memberikan ASI eksklusif sebanyak 10 orang $(45,5 \%)$ tidak mendukung dan 12 orang $(54,5 \%)$ mendukung.

Tabel 7. Gambaran dukungan nenek dalam keluarga extended family pada ibu yang memberikan ASI eksklusif berdasarkan indikator di Wilayah Kerja Puskesmas Arjasa

\begin{tabular}{|c|c|c|c|c|c|c|}
\hline \multirow{3}{*}{ Variabel } & \multicolumn{4}{|c|}{ Kategori } & \multirow{2}{*}{\multicolumn{2}{|c|}{ Total }} \\
\hline & \multicolumn{2}{|c|}{$\begin{array}{c}\text { Tidak } \\
\text { Mendukun } \\
\mathbf{g}\end{array}$} & \multicolumn{2}{|c|}{$\begin{array}{l}\text { Menduk } \\
\text { ung }\end{array}$} & & \\
\hline & $\mathbf{F}$ & $(\%)$ & $\mathbf{F}$ & $(\%)$ & $\mathbf{F}$ & 1 \\
\hline $\begin{array}{l}\text { Dukungan } \\
\text { Informasional }\end{array}$ & 8 & 36,4 & 14 & 63,6 & 22 & 100 \\
\hline $\begin{array}{l}\text { Dukungan } \\
\text { Penilaian }\end{array}$ & 11 & 50 & 11 & 50 & 22 & 100 \\
\hline $\begin{array}{l}\text { Dukungan } \\
\text { Emosional }\end{array}$ & 10 & 45,5 & 12 & 54,5 & 22 & 100 \\
\hline $\begin{array}{l}\text { Dukungan } \\
\text { Instrumental }\end{array}$ & 9 & 40,9 & 13 & 59,1 & 22 & 100 \\
\hline
\end{tabular}


Tabel 8. Gambaran dukungan nenek dalam keluarga extended family pada ibu yang memberikan ASI tidak eksklusif di Wilayah Kerja Puskesmas Arjasa

\begin{tabular}{|c|c|c|c|c|c|c|}
\hline \multirow{3}{*}{ Variabel } & \multicolumn{4}{|c|}{ Kategori } & \multirow{2}{*}{\multicolumn{2}{|c|}{ Total }} \\
\hline & \multicolumn{2}{|c|}{$\begin{array}{c}\text { Tidak } \\
\text { Mendukun } \\
\mathbf{g}\end{array}$} & \multicolumn{2}{|c|}{$\begin{array}{c}\text { Menduku } \\
\text { ng }\end{array}$} & & \\
\hline & $F$ & $(\%)$ & $F$ & $(\%)$ & $\bar{F}$ & $(\%)$ \\
\hline $\begin{array}{l}\text { Dukungan } \\
\text { nenek dalam } \\
\text { keluarga } \\
\text { extended } \\
\text { family }\end{array}$ & 23 & 52,3 & 21 & 47,7 & 44 & 100 \\
\hline
\end{tabular}

Tabel 9. Gambaran dukungan nenek dalam keluarga extended family pada ibu yang memberikan ASI tidak eksklusif berdasarkan indikator di Wilayah Kerja Puskesmas Arjasa

\begin{tabular}{|c|c|c|c|c|c|c|}
\hline \multirow{3}{*}{ Variabel } & \multicolumn{4}{|c|}{ Kategori } & \multirow{2}{*}{\multicolumn{2}{|c|}{ Total }} \\
\hline & \multicolumn{2}{|c|}{$\begin{array}{c}\text { Tidak } \\
\text { Mendukung } \\
\end{array}$} & \multicolumn{2}{|c|}{$\begin{array}{c}\text { Menduku } \\
\text { ng }\end{array}$} & & \\
\hline & $\mathbf{F}$ & $(\%)$ & $\mathbf{F}$ & $(\%)$ & $\mathbf{F}$ & (\%) \\
\hline $\begin{array}{l}\text { Dukungan } \\
\text { informasional }\end{array}$ & 17 & 38,6 & 27 & 61,4 & 44 & 100 \\
\hline $\begin{array}{l}\text { Dukungan } \\
\text { penilaian }\end{array}$ & 18 & 40,9 & 26 & 59,1 & 44 & 100 \\
\hline $\begin{array}{l}\text { Dukungan } \\
\text { emosional }\end{array}$ & 22 & 50 & 22 & 50 & 44 & 100 \\
\hline $\begin{array}{l}\text { Dukungan } \\
\text { instrumental }\end{array}$ & 12 & 27,3 & 32 & 72,7 & 44 & 100 \\
\hline
\end{tabular}

Tabel 10. Perbedaan dukungan nenek dalam keluarga extended family pada pemberian ASI eksklusif dan tidak eksklusif di Wilayah Kerja Puskesmas Arjasa

\begin{tabular}{|c|c|c|c|c|c|c|c|}
\hline \multirow{3}{*}{ Kategori } & \multicolumn{4}{|c|}{ Kelompok } & \multirow{2}{*}{\multicolumn{2}{|c|}{ Total }} & \multirow{3}{*}{$\begin{array}{c}p \\
\text { valu } \\
e\end{array}$} \\
\hline & \multicolumn{2}{|c|}{$\begin{array}{c}\text { ASI } \\
\text { Eksklusif }\end{array}$} & \multicolumn{2}{|c|}{$\begin{array}{l}\text { ASI Tidak } \\
\text { Eksklusif }\end{array}$} & & & \\
\hline & $F$ & (\%) & $F$ & (\%) & $F$ & (\%) & \\
\hline $\begin{array}{l}\text { Tidak } \\
\text { Mendukung }\end{array}$ & 10 & 45,5 & 23 & $\begin{array}{c}52, \\
3\end{array}$ & 22 & 100 & 0.001 \\
\hline Mendukung & 12 & 54,5 & 21 & $\begin{array}{c}47 \\
7\end{array}$ & 44 & 100 & \\
\hline
\end{tabular}

Hasil analisis diperoleh nilai $p$-value 0,001 $(<0,05)$. Hal ini menunjukkan bahwa hipotesis alternatif $(\mathrm{Ha})$ diterima yaitu ada perbedaan dukungan nenek dalam keluarga extended family pada pemberian ASI eksklusif dan tidak eksklusif di Wilayah Kerja Puskesmas Arjasa Kabupaten Jember.

\section{Pembahasan \\ Karakteristik Responden}

Responden baik yang memberikan ASI eksklusif maupun yang tidak eksklusif rata-rata adalah berumur 25 tahun. Menurut Pieter \& Lubis umur 25 tahun berada dalam rentang 21-35 tahun yang termasuk dalam kategori dewasa awal. Ciri-ciri masa dewasa awal adalah periode kebebasan untuk menentukan, mengatur pilihan yang ditetapkan dan kesiapan untuk menerima tanggung jawab [8].

Rata-rata umur bayi adalah berumur 9-10 bulan. Pada umur ini konsumsi ASI oleh bayi sudah berkurang dibandingkan usia dibawah 6 bulan karena bayi sudah mendapatkan nutrisi dari makanan tambahan. Bayi usia lebih dari 6 bulan harus mendapatkan makanan tambahan untuk menunjang pertumbuhannya. Pemberian makanan tambahan harus tepat waktu karena pemberian yang terlalu cepat maupun terlambat akan menyebabkan bayi mengalami masalah gizi baik kurang maupun lebih [9].

Distribusi agama responden seluruhnya beragama islam. Islam sebenarnya sudah menjelaskan tentang anjuran untuk memberikan ASI kepada bayinya dalam AlQuran Surat Al-Baqarah [2] ayat 233. Anjuran yang sudah tertulis seharusnya dapat dijadikan pedoman untuk ibu-ibu agar memberikan ASI kepada bayinya tidak digantikan dengan cairan selain ASI terutama di usia-usia awal kehidupani. Hal ini karena jumlah kandungan gizi yang ada pada cairan selain ASI melebihi kebutuhan bayi sehingga akan berdampak pada status gizi bayi [10].

Berdasarkan suku lebih dari setengah yaitu 43 orang $(65,2 \%)$ memiliki suku madura dan sisanya adalah suku jawa. Suku madura memiliki kebiasaan untuk memberikan MP-ASI dini kepada bayi. Jenis MP-ASI yang biasanya diberikan adalah pisang, madu atau kelapa muda [11]. Suku jawa juga memiliki budaya yang sama tentang pemberian MP-ASI dini [12].

Pada kelompok ibu yang memberikan ASI eksklusif paling banyak 7 orang $(31,8 \%)$ pendidikannya SMP dibandingkan kelompok ibu yang memberikan ASI tidak eksklusif yaitu 19 orang $(43,2 \%)$ berpendidikan SD. Hal ini sejalan dengan penelitian yang dilakukan Wahyuningsih bahwa semakin tinggi pendidikan ibu akan berpengaruh pada pengetahuan ibu menyusui mengenai ASI eksklusif [13].

Distribusi jenis pekerjaan ibu menunjukkan bahwa sebagian besar yaitu 57 
orang $(86,4 \%)$ merupakan ibu rumah tangga. Menurut penelitian yang dilakukan oleh Marpaung bahwa meskipun sebagian besar ibu yang menjadi responden dalam penelitiannya tidak bekerja atau ibu rumah tangga, ibu-ibu tidak memberikan ASI eksklusif kepada bayinya [14].

Distribusi pendapatan keluarga mayoritas mempunyai pendapatan dibawah Upah Minimum Kabupaten/Kota (UMK) Jember tahun 2016 yaitu 56 orang $(84,9 \%)$. Penelitian yang dilakukan Fatmawati menyatakan bahwa terdapat hubungan yang signifikan antara status ekonomi orangtua dengan pemberian ASI eksklusif. Orang tua yang memiliki status ekonomi rendah lebih banyak memberikan ASI tidak eksklusif dibandingkan orang tua dengan status ekonomi tinggi [15].

Distribusi jumlah anak lebih dari setengah berjumlah 1 yaitu 43 orang $(65,2 \%)$. Ibu yang pertama kali melahirkan dan menyusui, nenek berperan sebagai sumber dukungan yang paling penting untuk ibu sehingga keputusannya untuk memberikan ASI atau tidak sangat dipengaruhi oleh nenek [16].

Distribusi penyuluhan tentang ASI eksklusif sebagian besar pernah mendapatkan penyuluhan tentang ASI eksklusif dari petugas kesehatan yaitu 55 orang $(83,3 \%)$. Berdasarkan penelitian yang dilakukan oleh Retnani bahwa peranan dari petugas kesehatan seharusnya dapat mempengaruhi pola pikir responden yang nantinya akan menanamkan motivasi ibu untuk memberikan ASI eksklusif [17].

Promosi susu formula sebagian besar ibu terpapar yaitu 51 orang $(77,3 \%)$. Produk susu formula dipromosikan melalui iklan di media dan promosi di pertokoan. Penelitian yang dilakukan oleh Albab menyampaikan bahwa keterpaparan keluarga terhadap promosi susu formula cenderung mengalami ketidakberfungsian pengambilan keputusan keluarga untuk memberikan ASI eksklusif kepada bayinya [18].

\section{Dukungan Nenek dalam Keluarga Extended Family pada Ibu yang Memberikan ASI Eksklusif}

Berdasarkan tabel 6 pengkategorian dukungan nenek pada kelompok ASI eksklusif yaitu 22 orang $(54,5 \%)$ mendukung dalam pemberian ASI eksklusif. Berdasarkan indikator dukungan, indikator yang paling banyak memberikan dukungan adalah dukungan informasional yaitu 14 orang (63,6\%).

Dukungan informasional adalah bantuan informasi yang berupa nasihat, pengarahan atau ide-ide informasi yang dibutuhkan anggota keluarga untuk menghadapi persoalan [19]. Pada ibu menyusui nasihat yang diberikan yaitu nasihat untuk memberikan ASI saja sampai 6 bulan. Nenek sebagai anggota keluarga yang lebih berpengalaman dalam hal perawatan bayi terutama menyusui memiliki peran sebagai kunci dalam memutuskan menyusui dan waktu untuk memperkenalkan makanan tambahan kepada bayi [7].

Nenek dalam kelompok ibu yang memberikan ASI eksklusif lebih banyak tidak mendukung pada indikator dukungan penilaian yaitu 11 orang $(50 \%)$. Nenek yang memberikan dukungan penilaian kepada ibu akan berdampak pada kepercayaan diri ibu untuk melakukan praktik perawatan pada bayi termasuk dalam pemberian ASI. Menurut penelitian yang dilakukan oleh Warren dalam Orshan menyatakan bahwa dukungan penilaian memiliki hubungan yang signifikan terhadap kepercayaan diri ibu dalam memberikan perawatan kepada bayinya [20].

\section{Dukungan Nenek dalam Keluarga Extended Family pada Ibu yang Memberikan ASI Tidak Eksklusif}

Berdasarkan tabel 8 pengkategorian dukungan nenek pada kelompok ASI tidak eksklusif yaitu 23 orang $(52,3 \%)$ tidak mendukung dalam pemberian ASI eksklusif. Berdasarkan indikator yang paling besar tidak mendukung adalah indikator dukungan emosional yaitu sebesar 22 orang $(50 \%)$ bila dibandingkan dengan indikator-indikator lain. Menurut Anderson dukungan emosional dibutuhkan ibu untuk mampu menilai dirinya sendiri untuk mampu menyusui [21]. Penelitian yang dilakukan oleh Simbolon menyatakan bahwa ibu yang mendapatkan dukungan emosional yang baik mempunyai kemungkinan 28,216 kali akan memberikan ASI eksklusif dibandingkan ibu dengan dukungan emosional yang tidak baik [22].

Indikator yang lebih banyak mendukung pada kelompok ibu yang memberikan ASI tidak eksklusif adalah dukungan instrumental yaitu 32 orang $(72,7 \%)$. Dukungan intrumental yang diberikan nenek lebih kepada bantuan nyata seperti asistensi aktif dalam membantu keberhasilan menyusui ibu. Penelitian yang dilakukan oleh Emmot \& Mace menunjukkan bahwa bantuan praktis yang diberikan nenek dapat mempengaruhi rendahnya pemberian ASI eksklusif karena bantuan langsung oleh nenek untuk merawat bayi dapat mendorong ibu untuk memberikan susu formula kepada 
bayinya agar ibu dapat melakukan aktifitas lainnya [23].

\section{Perbedaan Dukungan Nenek dalam Keluarga Extended Family pada Pemberian ASI Eksklusif dan Tidak Eksklusif}

Hasil penelitian menunjukkan adanya perbedaan dukungan nenek dalam keluarga extended family pada pemberian ASI eksklusif dan tidak eksklusif karena didapatkan hasil pvalue $=0,001<\alpha=0,05)$. Pada kelompok ibu yang memberikan ASI eksklusif dukungan nenek dalam kategori mendukung sejumlah 12 orang $(54,5 \%)$ dan tidak mendukung 10 orang $(45,5 \%)$. Pada ibu yang memberikan ASI eksklusif lebih dari setengahnya mendapatkan dukungan. Nenek pada kelompok ibu yang memberikan ASI eksklusif rata-rata menurut tabel 4 adalah umur 50,86 tahun. Usia 50 tahun digolongkan dalam lanjut usia dan salah satu tugas perkembangan lanjut usia adalah mendefinisikan ulang hubungan dan sering memerlukan penetapan hubungan dengan anak-anaknya yang telah dewasa dengan berbagi pengalaman tentang kehidupannya untuk menetapkan perannya sebagai orangtua [24].

Status nenek dengan ibu sebagian besar adalah sebagai ibu kandung yaitu 17 orang $(77,3 \%)$. Berdasarkan penelitian yang dilakukan oleh Susin, Giugliani, dan Kummer menyebutkan bahwa nenek yang berstatus ibu kandung memiliki pengaruh nasihat lebih besar untuk mempengaruhi ibu dibandingkan nasihat dari ibu mertua [5].

Hasil penelitian ibu yang memberikan ASI eksklusif tidak mendapatkan dukungan dari nenek yaitu 10 orang $(45,5 \%)$ tetap memberikan ASI eksklusif kepada bayinya. Salah satu faktor yang mempengaruhi hal tersebut karena usia ibu. Kelompok ibu yang memberikan ASI eksklusif rata-rata usianya termasuk dewasa awal jadi meskipun nenek tidak mendukung pemberian ASI eksklusif, ibu memiliki keputusan sendiri akan memberikan ASI eksklusif kepada bayinya karena masa dewasa awal adalah salah satunya sebagai masa komitmen yaitu mulai belajar bertanggung jawab, dan tidak bergantung lagi pada orang tua dalam mengambil keputusannya [8].

Pada kelompok ibu yang memberikan ASI eksklusif lebih banyak yaitu $86,4 \%$ ibu mendapatkan penyuluhan tentang ASI eksklusif daripada kelompok ibu yang memberikan ASI tidak eksklusif. lbu yang mendapatkan penyuluhan tentang ASI eksklusif akan memiliki pengetahuan dan sikap yang lebih baik dibandingkan ibu yang tidak mendapatkan penyuluhan [25].

Selain usia dan penyuluhan tentang ASI eksklusif pada kelompok ibu yang memberikan ASI eksklusif lebih banyak tidak terpapar informasi tentang susu formula yaitu $27,3 \%$. Hal ini sesuai dengan penelitian yang dilakukan oleh Fahma bahwa terdapat hubungan antara promosi susu formula dengan pemberian ASI eksklusif pada bayi usia 7-12 bulan [26].

Hasil penelitian pada tabel 8 menunjukkan bahwa pada kelompok ibu yang memberikan ASI tidak eksklusif menunjukkan bahwa lebih dari setengah ibu tidak mendapatkan dukungan yaitu 23 orang $(52,3 \%)$. Nenek sebagai orang yang lebih tua dan berpengalaman daripada ibu memiliki pengaruh pada keputusan ibu untuk memberikan ASI eksklusif atau tidak. Menurut penelitian yang dilakukan oleh Kerr et all pada keluarga dengan tipe extended family nenek masih cenderung ingin memberikan makanan tambahan dini kepada bayi seperti pengalaman-pengalaman terdahulunya [27]. Pengalaman pemberian makanan tambahan dini inilah yang menjadi salah satu penyebab ibu tidak memberikan ASI eksklusif [6].

Pada penelitian ini lebih dari setengahnya responden adalah berbudaya Madura. Menurut penelitian yang dilakukan oleh Firdhani \& Gunanti menyebutkan bahwa ada madura memiliki budaya memberikan makanan padat saat bayi kurang dari 4 bulan biasanya diberikan pisang halus [11]. Selain madura, budaya jawa juga memiliki kebiasaan yang sama dalam pemberian makanan prelekteal kepada bayinya [12].

Hasil penelitian pada Tabel 8 menunjukkan bahwa kurang dari setengah pada kelompok ibu yang memberikan ASI tidak eksklusif mendapatkan dukungan yaitu 21 orang $(47,7 \%)$. Dalam kelompok ibu yang memberikan ASI tidak eksklusif pada tabel 3 menunjukkan bahwa hampir setengahnya memiliki pendidikan SD yaitu 19 orang $(43,2 \%)$. Ibu yang berpendidikan dasar umumnya kurang terbuka terhadap penerimaan dalam perubahan dan informasi baru tentang pemberian ASI sehingga akan berdampak terhadap pengetahuan ibu tentang ASI [17].

Status ekonomi rendah lebih banyak pada kelompok ibu yang memberikan ASI tidak eksklusif dibandingkan kelompok ibu yang memberikan ASI eksklusif. Menurut Wambach status ekonomi juga merupakan salah satu 
faktor yang dapat mempengaruhi pemberian ASI [7].

Hasil penelitian ini menunjukkan bahwa nenek memiliki peran penting untuk ibu agar ibu dapat menyusui bayinya secara eksklusif. Diharapkan nenek dapat meningkatkan dukungannya kepada ibu sehingga dapat meningkatkan angka cakupan ASI eksklusif khususnya di Kecamatan Arjasa Kabupaten Jember.

\section{Simpulan dan Saran}

Terdapat perbedaan dukungan nenek dalam keluarga extended family pada pemberian ASI eksklusif dan tidak eksklusif. Perawat dapat memberikan implikasi keperawatan dalam lingkup maternitas dan komunitas melalui penyuluhan tentang ASI eksklusif dan pentingnya dukungan dari nenek. Bagi peneliti selanjutnya diharapkan melaksanakan riset lebih lanjut dalam mengidentifikasi dukungan nenek dari sudut pandang nenek dan faktor lain yang mempengaruhi tidak diberikannya ASI eksklusif selain faktor dukungan dari keluarga.

\section{Daftar Pustaka}

[1] Indonesia. Kementerian Kesehatan RI. Pedoman gizi seimbang. [Internet]. 2014. [diambil tanggal 2 Februari 2016]; dari: http://www.hukor.depkes.go.id/uploads/produ k_hukum/PMK\%20No.\%2041\%20ttg

\%20Pedoman\%20Gizi\%20Seimbang.pdf

[2] Yuliarti N. Keajaiban ASI makanan terbaik untuk kesehatan. Yogyakarta: Andi; 2010

[3] Infodatin Kemenkes RI. Kondisi pencapaian program kesehatan anak indonesia. [Internet]. 2014. [diambil tanggal 25 Desember 2015]; dari: http://depkes.go.id/download.php? file=download.pdf

[4] Maryunani A. Inisiasi menyusu dini, ASI eksklusif dan manajemen laktasi. Jakarta: TIM; 2012

[5] Susin LR, Giugliani ER, dan Kummer, SC. Influence of grandmothers on breastfeeding practice. [Internet]. 2005. [diambil tanggal 10 Februari 2016]; dari: http://www.ncbi.nlm.nih.gov/pubmed/158951 30

[6] Firanika R. Aspek budaya dalam pemberian ASI eksklusif di Kelurahan Bubulak Kota Bogor tahun 2010. [Internet]. 2010. [diambil tanggal 8 Maret 2016]; dari: http://repository.uinjkt.ac.id/dspace/bitstream /123456789/1024/1/RAYUNI\%20FIRANIKAFKIK.pdf
[7] Wambach K \& Riordan J. Breastfeeding and human lactation. USA: Library of Congress Cataloging; 2014

[8] Pieter HZ \& Lubis NL. Pengantar psikologi dalam keperawatan. Jakarta: Kencana; 2012

[9] Mutalib. Pemberian MP-ASI dan status gizi bayi usia 6-24 bulan berdasarkan indeks BB/U di Desa Ban Kecamatan Kubu tahun 2014. [Internet]. 2014. [diambil tanggal 11 Mei 2016] dari: https://wisuda.unud.ac.id/pdf/1002006201 -1-Jurnal\%20akmal\%20hakim.pdf

[10] Proverawati A \& Rahmawati E. Kapita selekta ASI dan menyusui. Yogyakarta: Nuha Medika; 2010

[11] Firdhani AE \& Gunanti IR. Pola pemberian ASI, MP-ASI dan status gizi anak usla 1-2 tahun pada keluarga etnis Madura dan etnis Arab (studi di Puskesmas Pegirian dan puskesmas perak timur surabaya). [Internet]. 2005. [diambil tanggal 8 Maret 2016]; dari: http://download.portalgaruda.org/article.ph p?article $=80510 \& \mathrm{val}=4892$

[12] Utami LH. Budaya pemberian makanan pendamping ASI dini pada ibu yang mempunyai anak 7-24 bulan di Desa Argodadi Sedayu Bantul Yogyakarta. [Internet]. 2010. [diambil tanggal 25 Februari 2016]; dari: http://opac.say.ac.id/1119/

[13] Wahyuningsih. Perbedaan status ekonomi dan dukungan suami antara kelompok ibu yang memberikan ASI eksklusif dan ibu yang tidak memberikan ASI eksklusif di Puskesmas Wonogiri II. [Internet]. 2014. [diambil tanggal 10 Mei 2016]; dari: www.jurnal.stikes-aisyiyah.ac.id > Beranda > Vol 11, No 1 (2014) > Wahyuningsih

[14] Widuri H. Cara mengelola ASI eksklusif bagi ibu bekerja. Yogyakarta: Gosyen; 2013

[15] Fatmawati AP. Hubungan status ekonomi orang tua dengan pemberian ASI eksklusif pada bayi usia 0-6 bulan di Baki Sukoharjo. [Internet]. 2013. [diambil tanggal 25 Mei 2016]; dari: http://eprints.ums.ac.id>02._naskah_publi kasi.pdf

[16] Grassley JS \& Eschiti V. Grandmothers breastfeeding support : what do mothers need and want? [Internet]. 2009. [diambil tanggal 8 Maret 2016]; dari: http://www.ncbi.nlm.nih.gov/pubmed/1903 6046 
[17] Retnani AD. Hubungan peran petugas kesehatan dengan motivasi ibu dalam pemberian ASI eksklusif di Desa Wonorejo Kecamatan Kencong Kabupaten Jember. Skripsi. Jember. Universitas Jember; 2015

[18] Albab FU. Hubungan promosi susu formula dengan pengambilan keputusan keluarga dalam pemberian ASI eksklusif di wilayah kerja Puskesmas Arjasa Kabupaten Jember. Skripsi. Jember. Universitas Jember; 2013

[19] Setiadi. Konsep dan proses keperawatan keluarga. Yogyakarta: Graha IImu; 2008

[20] Orshan S. Maternity, newborn, and women's health nursing : comprehensif care across the lifespan. Philadelphia: Wolter Kluwer; 2008

[21] Anderson BA. Caring for the vulnerable: perspectives in nursing theory, practice and research 3rd ed. India: Ascend Learning; 2012

[22] Simbolon P. Pengaruh dukungan keluarga terhadap pemberian ASI eksklusif di wilayah kerja Puskesmas Gurolla Pematangsiar. [Internet]. 2012. [diambil tanggal 21 Desember 2015]; dari: http://repository.usu.ac.id/handle/123456789/ 31289

[23] Emmot EH \& Mace R. Practical support from fathers and grandmothers is associated with lower levels of breastfeeding in the uk millenium cohort study. [Internet]. 2015. [diambil tanggal 21 Desember 2015]; dari: http://journals.plos.org [11 Mei 2016]

[24] Klossner NJ. Introductory maternity nursing.
USA:Lippincott Williams \& Wilkins; 2006

[25] Merdhika WA, Mardji dan Devi M. Pengaruh penyuluhan ASI eksklusif terhadap pengetahuan ibu tentang ASI eksklusif dan sikap ibu menyusui di Kecamatan Kanigoro Kabupaten Blitar. [Internet]. 2014. [diambil tanggal $25 \mathrm{Mei}$ 2016];

dari:

http://Webcache.Googleusercontent.Com/

Search?

$\mathrm{Q}=$ Cache:Aubvaokgwcej:Journal.Um.Ac.I

d/Index.Php/Teknologi-

Kejuruan/Article/Download/4108/725+\&Cd

$=1 \& H I=|d \& C t=C \operatorname{lnk} \& G|=\mid d$

[26] Fahma FF, Tarmali A, Widyanti SA. Hubungan dukungan suami dan promosi susu formula dengan pemberian ASI eksklusif pada bayi usia 7-12 bulan di Kelurahan Pringapus Kecamatan Pringapus Kabupaten Semarang. [Internet]. 2014. [diambil tanggal $25 \mathrm{Mei}$ 2016];

dari: http://perpusnwu.web.id/karyailmiah/docu ments/3864.pdf

[27] Kerr RB. We grandmothers know plenty: breastfeeding, complementary feeding and the multifaceted role of grandmothers in malawi. [Internet]. 2007. [diambil tanggal 2 Februari 2016]; dari: http://www.ncbi.nlm.nih.gov/pubmed/1815 5 